\title{
Contribution to the knowledge of Bosellia mimetica Trinchese, I89 I (Gastropoda Sacoglossa) and its seasonality along the central-eastern coast of Sicily (Ionian Sea)
}

\author{
Andrea Lombardo \& Giuliana Marletta \\ ${ }^{1}$ Department of Biological, Geological and Environmental Sciences, University of Catania, 95124 Catania, \\ Italy \\ Corresponding author, e-mail: andylombardo94@gmail.com
}

\begin{abstract}
Bosellia mimetica Trinchese, 1891 is a sacoglossan which lives in close relationship with the green alga Halimeda tuna that represents its source of food and substrate. The name $B$. mimetica comes from the ability of this sea slug to perfectly mimic H. tuna. The aim of the present research was to achieve new knowledge on this species and its seasonality along the central-eastern coast of Sicily (Italy). Data on the seasonality of B. mimetica have been collected from 2018 to 2020 through underwater visual census with scuba dive. Through data collection, it has been observed that $B$. mimetica is mostly present in spring and summer and it declines from the end of summer to autumn. Occasionally, a few rare specimens have also been found during winter months. The factors which mostly seem to control B. mimetica's seasonality could be the daylength and the temperature. Although this species shows antipredatory cryptic and chemical defences, through data collection it has been observed that several $B$. mimetica specimens presented evident crescent-shape injuries resembling the bites on $H$. tuna. We believe that the most probable candidate as possible grazer of this seaweed is the parrotfish Sparisoma cretense. Consequently, $S$. cretense could involuntarily prey on $B$. mimetica when it rests on $H$. tuna.
\end{abstract}

KEY WORDS Bosellia mimetica; Halimeda tuna; Sacoglossa; Seasonality; Sicily.

Received 03.01.2021; accepted 09.04.2021; published online 28.04.2021

\section{INTRODUCTION}

Bosellia mimetica Trinchese, 1891 is a sacoglossan belonging to the family Plakobranchidae Gray, 1840 (Figs. 1-3). This species presents a dorso-ventrally flattened body, which can change shape depending on the activity of the animal: elongated when the species is crawling and circular when it rests or feeds (Trinchese, 1890). The head and the foot are separated from the rest of the body by symmetrical transverse folds. Rhinophores are very short, longitudinally folded and opened on the ventral side. The colour of the body is bright green and sometimes white blotches can be present on it. Often the notum is bordered with irregularly tiny white spots (Schmekel \& Portmann, 1982). Moreover, when the species is contracted, a pattern of blood vessels can be distinguished in dorsal view (Thompson \& Jaklin, 1988). Although this species is characterized by a green-coloured body, some specimens with a white body and green streaks have been observed by Perrone (1983). This sacoglossan 
can reach a maximum size of $25 \mathrm{~mm}$ (Trainito \& Doneddu, 2014).

Bosellia mimetica is distributed in the Mediterranean, along the Atlantic coasts of the Iberian Peninsula, in the Caribbean and Brazil (Trainito \& Doneddu, 2014). This species has sedentary habits, constantly residing on its source of food, the green seaweed Halimeda tuna (J. Ellis et Solander) J.V. Lamouroux. In fact, this sea slug, modifying the shape of its body, mimics the segments which compose the thallus of the seaweed (Trinchese, 1890). Indeed, this species, when is not on $H$. tuna, presents an elongated shape of the body, while when it is on H. tuna, this animal tries to assume a very flattened and oval shape resembling the shape of the seaweed (Portmann, 1958). Although the principal source of food and substrate of $B$. mimetica is $H$. tuna, this species has also been reported on another green siphonous seaweed, Flabellia petiolata (Turra) Nizamuddin (Thompson \& Jaklin, 1988; Trainito $\&$ Doneddu, 2014). B. mimetica has been found from 2 to $100 \mathrm{~m}$ of depth, in both shallow and deep waters (Trinchese, 1890; Perrone, 1983; Thompson and Jaklin, 1988; Marín and Ros, 1988). Bosellia mimetica's egg masses are flattened and with a spiro-planal shape, containing yellow or greenish eggs. Usually, the spawn is laid on H. tuna or F. petiolata (Portmann, 1958; Schmekel \& Portmann, 1982; Thompson \& Jaklin, 1988). The egg masses (Figs. 4-5) have been reported during summer months (Thompson \& Jaklin, 1988) and from May to June and November (Portmann, 1958) and in October (Marín \& Ros, 1988).

$B$. mimetica bears its name from the ability to perfectly mimic the substrate, $H$. tuna, on which it lives (Trinchese, 1890). Ros (1976) described that this species uses its white pigments to imitate the epibionts (hydrozoans, bryozoans, encrusting algae and serpulids) that commonly live on $H$. tuna. Instead, the bright green colour of the animal comes from $H$. tuna's pigments, which are used to resemble this seaweed. Together with the cryptism strategy, this sea slug accumulates from $H$. tuna the metabolite halimedatrial (Marín \& Ros, 2004), which has cytotoxic, antimicrobial and feedingdeterrent activities (Paul \& Fenical, 1987), used as chemical defence against possible predators.

Moreover, B. mimetica, as other Sacoglossa, can retain and use the chloroplasts of algae (in this case those of $H$. tuna) to obtain the products of the photosynthesis (Marín \& Ros, 1988). In particular, B. mimetica has a short-term retention of chloroplasts which lasts about one week (Händeler et al., 2009).

Although the seasonality of other Sacoglossa, such as Elysia timida (Risso, 1818), has already been studied (e.g., Ros \& Marín, 1991), the seasonality of $B$. mimetica is still poorly known. Therefore, the aim of the present research was to fill this gap and to report new data on this species.

\section{MATERIAL AND METHODS}

The present study has been carried out from 2018 to 2020 in different areas located along the central-eastern coast of Sicily (Italy) (Figs. 6-7).

Three study areas, Catania, Santa Maria La Scala and Santa Tecla, have been chosen according to different environmental conditions. In Catania, two sites, Ognina (37 $\left.31^{\prime} 50.4^{\prime \prime} \mathrm{N}-15^{\circ} 07^{\prime} 10.8^{\prime \prime} \mathrm{E}\right)$ and Bellatrix (37 $\left.32^{\prime} 03.2^{\prime \prime} \mathrm{N}-15^{\circ} 07^{\prime} 35.2^{\prime \prime} \mathrm{E}\right)$, present both a strong human impact. In fact, in these zones there are a manifold, a harbour, apartment buildings and bathing establishments. Due to their proximity and the similar environmental conditions, these two sites were considered as a single study area named "Catania". The area of Santa Maria La Scala (3736’46.5” N - 15¹0’31.4” E) shows intermediate environmental conditions between those of Catania and Santa Tecla. Indeed, in Santa Tecla, two sites, Acque Fredde (37³8'15.7' N $\left.15^{\circ} 10^{\prime} 52.1^{\prime \prime} \mathrm{E}\right)$ and Scalo Pennisi (37'38'23.2” N $-15^{\circ} 11^{\prime} 04.6$ " E) present both the most natural conditions among the study areas. Moreover, both zones are located close to each other and, thus, have been regarded as a single site named "Santa Tecla".

Data on the seasonality of $B$. mimetica have been collected through underwater visual census with scuba dive. A total of 234 dives (68 in Santa Maria La Scala, 95 in Catania and 71 in Santa Tecla) have been conducted all year round (marineweather conditions permitting), twice a week, during daylight, between 9-11:30 am. For each diving site (with range of depth between 0-45 m, according to the seabed geomorphology) the same path was carried out and all $B$. mimetica's specimens and their egg masses were photographed with an Olympus TG-4 underwater camera and counted in situ. Moreover, for each specimen, also 
information on depth and substrate, when different from $H$. tuna, has been annotated.

Through Excel, the average number of specimens per month for each site (from 2018 to 2020) has been calculated, and graphics have been produced. Furthermore, to simplify the representation of $B$. mimetica's seasonality, a single graph for each site (Catania, Santa Maria La Scala and Santa Tecla) has been realized by averaging the seasonal trends from 2018 to 2020 .

Because of the lockdown due to Covid-19, the diving activities foreseen in April 2020 have not
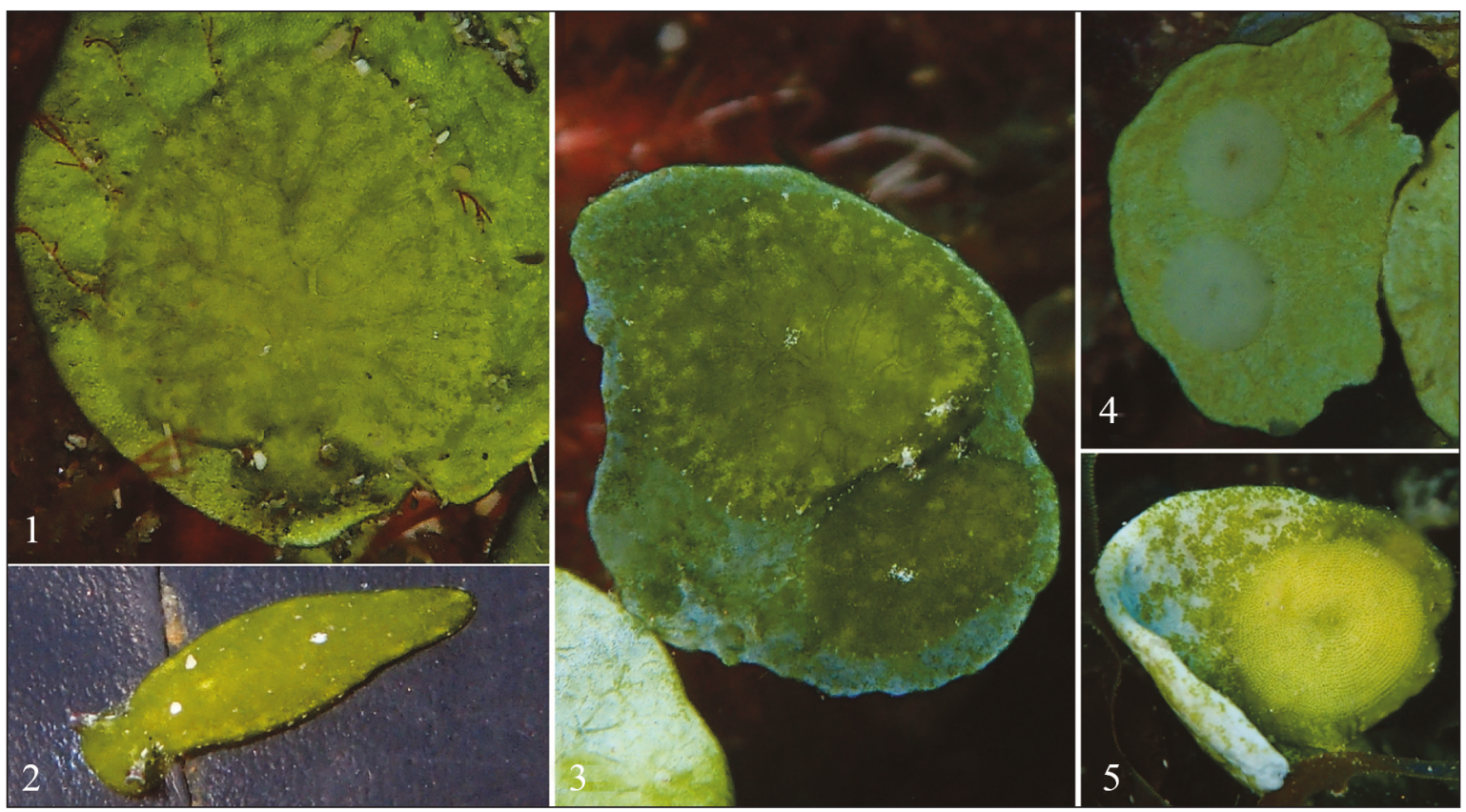

Figures 1-5. Bosellia mimetica's specimens from the central-eastern coasts of Sicily. Fig. 1: Dorsal view of a contracted specimen on Halimeda tuna. Fig. 2: Specimen in the typical elongated shape. Fig. 3: Two specimens before breeding. Fig. 4: Greyish egg masses on H. tuna. Fig. 5: Yellow egg mass on H. tuna (photos by A. Lombardo).

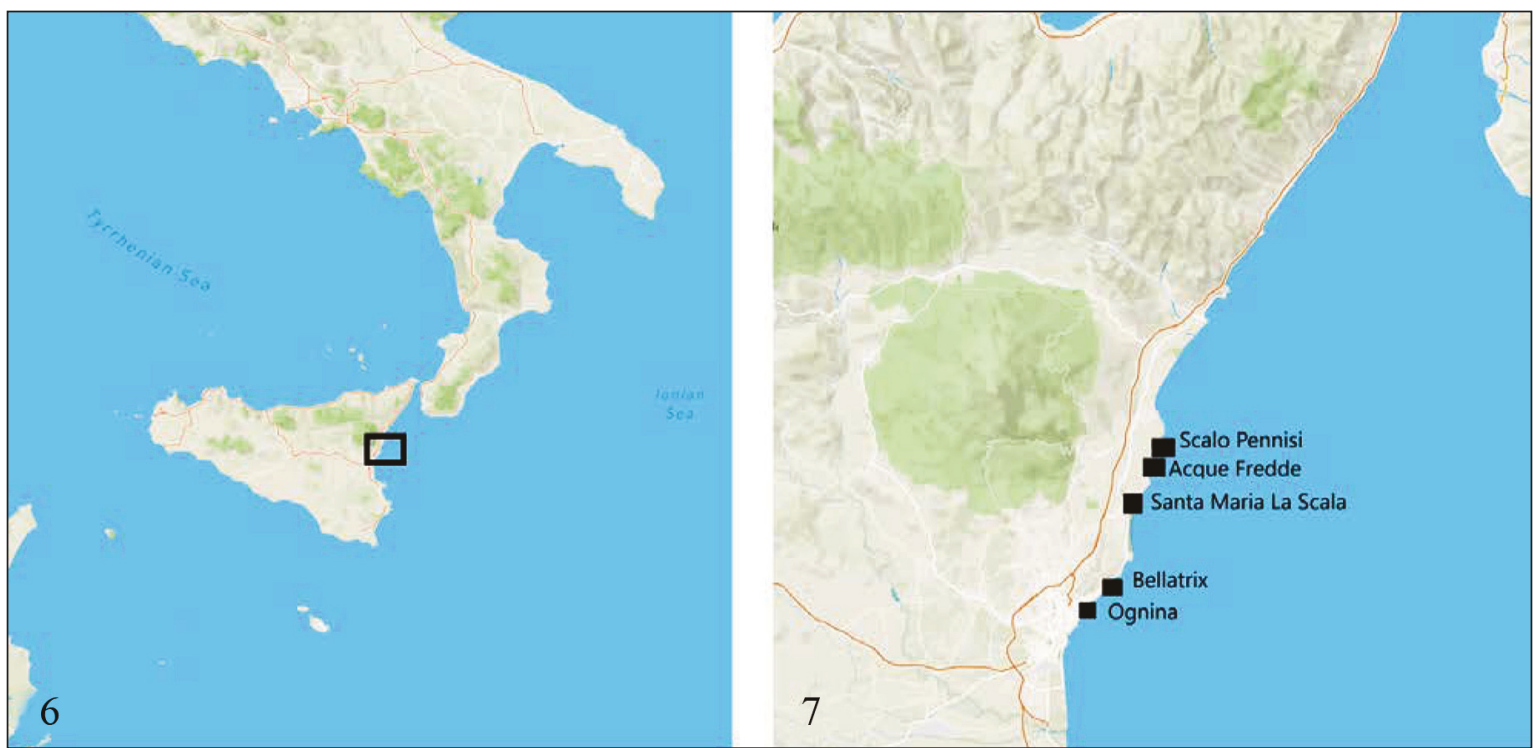

Figures 6, 7. Location of the study area. Fig. 6: central-eastern coast of Sicily. Fig. 7: study sites. 
been conducted, thus, the mean number of $B$. mimetica's specimens for this month has been calculated through the average number of specimens between March 2020 and May 2020.

\section{RESULTS}

\section{Catania (Fig. 8)}

In the site of Catania, throughout the years of study a total average number of $B$. mimetica's specimens equal to 4.15 has been observed. In 2018, during winter months (January, February) no individual of this species has been found. Instead, between March and April, an increase in the average number of specimens has been observed. This rise led in April to a peak of the population, which then started to decrease until June. Subsequently, an increment in the average number of specimens occurred until July. After this second peak, the population decreased until November, from which no specimen has been seen anymore. During 2018, the egg masses have been documented in May, July, August and September, always on $H$. tuna. Throughout 2018, no breeding activity has been observed.

In 2019, between January and March a strong rise of the population happened, carrying to the peak of March. Subsequently, a decrease in the average number of specimens occurred until August. Then, an isolated little increment in September has been registered. After that, the population almost disappeared in October and a new rise began in December. During 2019, the egg masses have been recorded in June, July and from September to December, always on $H$. tuna. The reproductive activity has been spotted only in July.

In 2020, between January and February an increase in $B$. mimetica's population has been observed. Then, from February to March there was a slight decline and later, a new rise which led to the peak of May. Subsequently, the average number of specimens maintained almost stable until September. Therefore, a decrement in the average number of specimens has carried to the disappearance of the population in December. During this year, the egg masses have been found in February and from May to December, each time on $H$. tuna. The breeding activity has been observed in May and August.
In the site of Catania, B. mimetica's specimens and their egg masses have been seen in a range of depth of $17.5-39.4 \mathrm{~m}$.

\section{Santa Maria La Scala (Fig. 9)}

In this site, a total average number of $B$. mimetica specimens amounting to 3.24 has been found throughout the years of study. In 2018, during the first months of the year (January and February) no individual has been observed. Then, between March and May, a rise in the average number of specimens carried to the peak observed in May. Subsequently, from May to October the population trend was almost stable, except in August, when a slight decrement occurred. From October there was a strong decrease in the population, which has undergone to disappearance in November and December. In 2018, the egg masses have been found from May to October, always on H. tuna. The breeding activity has been observed only in July.

In 2019, an increase in the average number of specimens occurred from February to April, then, a strong rise in the population led to the peak observed in May. After that, a slight decrease happened in June and, in July the population has almost returned to the number observed in May. Subsequently, from July to August a strong decline occurred and then a constant decrease in the average number of specimens happened in November. During 2019, the egg masses, laid on H. tuna, have been found from March to December. The reproductive activity has been registered only in July.

In 2020, B. mimetica's population started to increase from February to June, in which the highest average number of specimens for that year has been found. Subsequently, from June there was a decrease of the population observed until December. During 2020, the egg masses has been reported in March and from May to October, on $H$. tuna. The breeding activity has been registered only in September.

In Santa Maria La Scala, both B. mimetica's specimens and their egg masses have been observed in a range of depth of 13.6-37.4 m.

\section{Santa Tecla (Fig. 10)}

In the site of Santa Tecla, from 2018 to 2020, a total average number of $B$. mimetica's specimens 
corresponding to 0.97 has been found. In 2018, the population began to increase in June, reaching a peak in July and then, it decreased until October. During this year, the egg masses have been recorded from June to September, on H. tuna. Instead, the reproductive activity has not been observed throughout the year.

In $2019, B$. mimetica's population started to increase from May to June, period in which a peak in the average number of specimens has been observed. Therefore, there was an almost constant trend in the average number of specimens from June to August, in which a strong decrease occurred until September, when the population completely disappeared. During 2019, the egg masses, laid on H. tuna, have been seen in June, August and October. Also, during this year, no breeding activity has been detected.

In $2020, B$. mimetica's population began to appear in May and a strong increase occurred until August. Then, a strong decline in the average number of specimens has been registered until September. A few specimens have been observed between September and November. During this year, the egg masses have always been seen on $H$. tuna in June and July, while the reproductive activity has not been observed.

In this site, all $B$. mimetica's specimens and their egg masses have been found from 13.7 to $27.4 \mathrm{~m}$ of depth.

\section{Further remarks}

Throughout this study, several B. mimetica's specimens, with white pigments covering most of the body, have been observed (Figs. 11-14). Moreover, some specimens, showing an intermediate body colouring between green and white, have also been documented (Figs. 15-16). All B. mimetica's egg masses were yellow-coloured or greyish-coloured.

During this study, many $H$. tuna's thalli, on which there were both $B$. mimetica individuals and/or egg masses, displayed crescent-shaped bites, due possibly to the grazing of one or some herbivorous fishes (Figs. 17-19). Moreover, some B. mimetica specimens presented injuries with the same shape of the bites on H. tuna (Figs. 19-21). Few specimens have been found on substrates different from H. tuna: F. petiolata, Caulerpa cylindracea

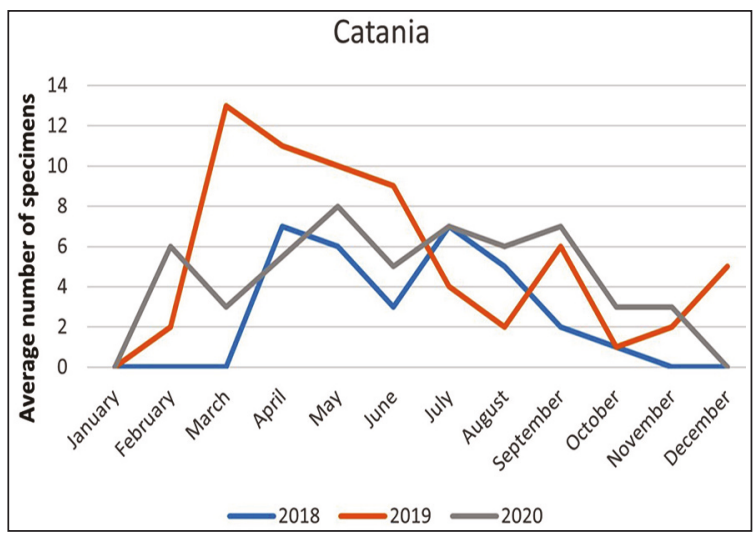

Figure 8. Seasonal trends of the average number of Bosellia mimetica's specimens from 2018 to 2020 in Catania.

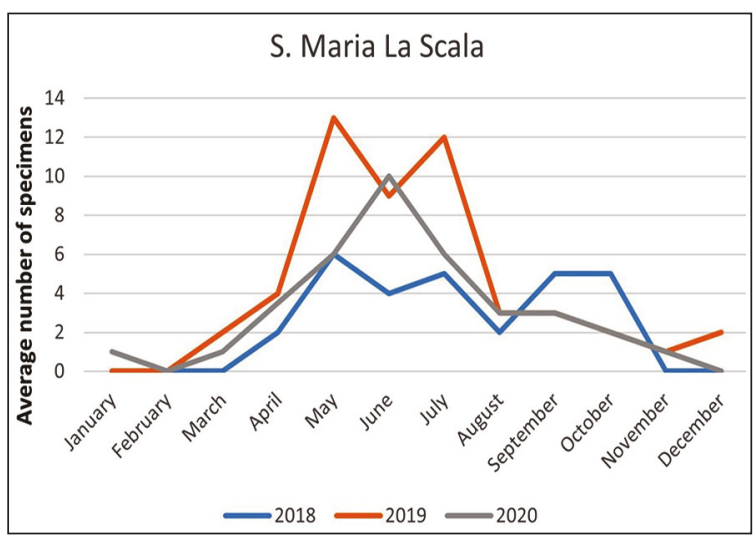

Figure 9. Seasonal trends of the average number of Bosellia mimetica's specimens from 2018 to 2020 in Santa Maria La Scala.

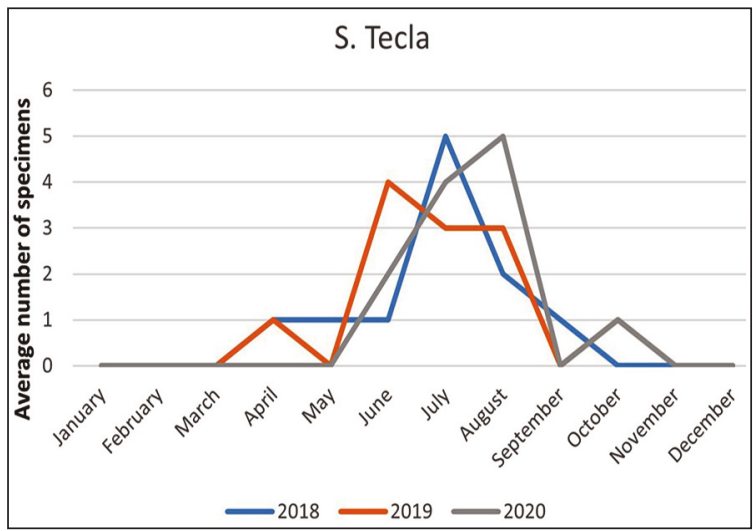

Figure 10. Seasonal trends of the average number of Bosellia mimetica's specimens from 2018 to 2020 in Santa Tecla. 
Sonder, Dictyota dichotoma (Hudson) J.V. Lamouroux, D. implexa (Desfontaines) J.V. Lamouroux, Laurencia sp., Radicilingua sp., turfforming Rhodophyta, Rhodymenia pseudopalmata (J.V. Lamouroux) P.C. Silva, tunicates and bryozoans. The only substrate, besides $H$. tuna, on which $B$. mimetica has been found in the characteristic contracted shape was $F$. petiolata.

\section{DISCUSSION}

Through the present study, the seasonality of $B$. mimetica along the central-eastern sector of Sicily has been detected. In particular, the seasonality of this species has been analysed in three sites and for each of them a summarising graph (for the three years of study) has been produced.

Catania (Fig. 22) was the site among those studied with the highest total average number of specimens. In this area, overall over the years of study, B. mimetica population was present almost all year round. From January to April-May a strong increase in the average number of specimens has been noted. Indeed, the months in which the population reached its peak were April and May.
Then, a constant decrement occurred until October, after which $B$. mimetica almost disappeared in this site. Therefore, this species in Catania is strongly present in spring, starts to decrease during summer and then disappears at the beginning of autumn.

Santa Maria La Scala (Fig. 23) presented an average number of specimens intermediate between Catania and Santa Tecla. In this site, B. mimetica's recruitment began at the end of February and continued until May, in which the highest presence of this species has been observed until July. Then, there was a constant decrement until November. Consequently, also in this site $B$. mimetica presents a remarkably spring seasonality that starts to decrease in the mid-summer.

Santa Tecla (Fig. 24) was the site with the lowest average number of specimens among the study areas. Here, the population presented a remarkably summer seasonality than the other sites. In fact, $B$. mimetica's recruitment started in May and finished in July, after which a strong decline has been registered until September-November.

Through the collected data and the graphic representation, it can be observed that $B$. mimetica is a species mostly present in spring and summer and it declines from the end of summer to autumn.
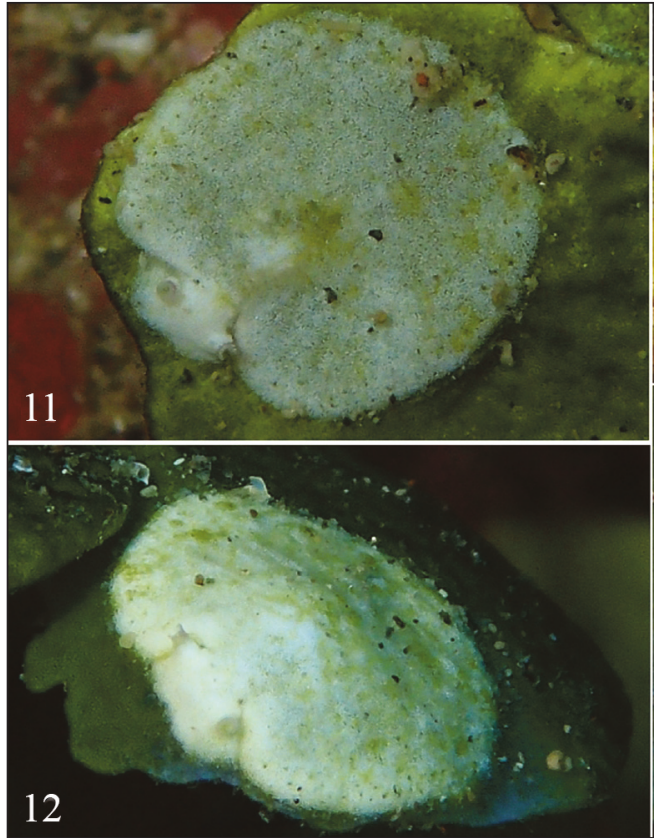
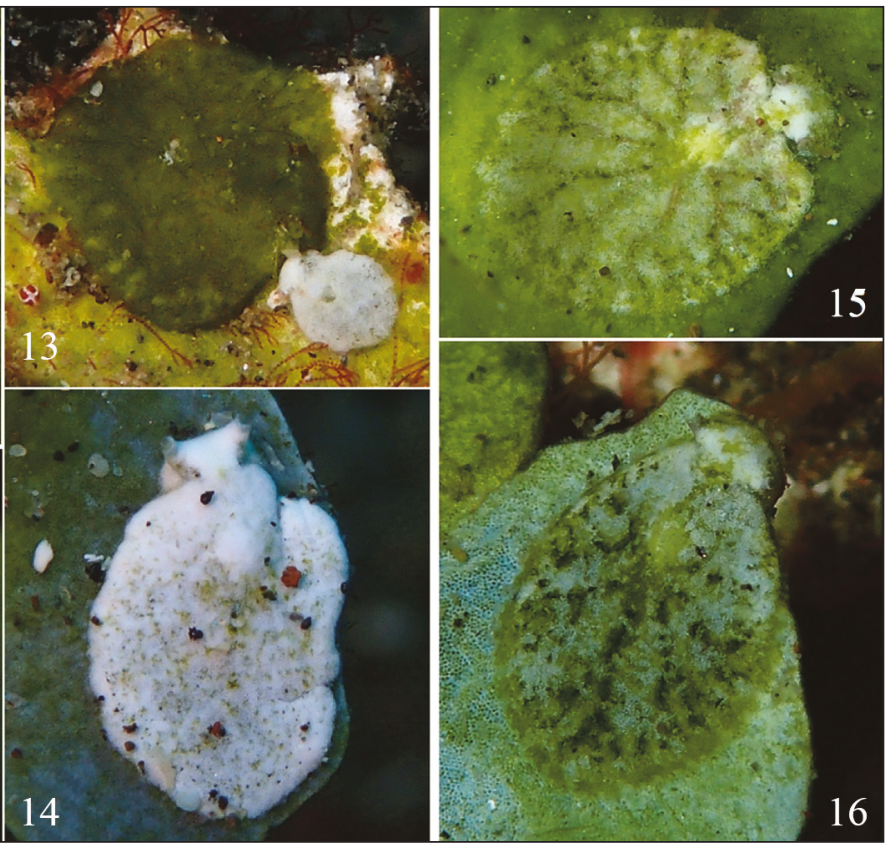

Figures 11-16. White-pigmented Bosellia mimetica. Fig. 11: dorsal view of a white B. mimetica. Fig. 12: antero-dorsal view of a specimen. Fig. 13: breeding between a green specimen and a white specimen. Fig. 14: dorsal view of a specimen; Fig. 15: intermediate white-green specimen; Fig. 16: another white-green pigmented specimen (photos by A. Lombardo). 
In particular, comparing the graphs of each site, it can be seen that proceeding from Catania towards Santa Tecla, along a south-north gradient, the average number of $B$. mimetica's individuals decreases and the maximum presence of this species is condensed into narrower periods that are increasingly shifted towards the summer season. This trend can be explained by two reasons. The reduced average number of specimens observed proceeding towards north might be due because the $B$. mimetica's veligers come from south and thus Catania is the site which receives the highest number of larvae. Furthermore, the second reason could depend on the fact that both in Santa Maria La Scala and particularly in Santa Tecla, there are spring waters coming from Etna (Catra et al., 2006) which might maintain the seawater locally cooler than Catania and thus, being B. mimetica a warmwater species (Thompson \& Jaklin, 1988), in these sites it can be present with a higher number only in late spring and summer. On the contrary, in Catania, this species can be present for a larger period throughout the year. Regardless, although this species has a warm-water affinity, rarely some specimens have been found also in winter months (December-January-February). Moreover, through data collection, it has been noted that this species can spawn almost all year round, except in January. Therefore, probably, this species can be present in all seasons because its source of food, H. tuna, is always available during the year (Meinesz, 1980; Ballesteros, 1991). However, in the present study emerges that $B$. mimetica is strongly present in spring and summer. Consequently, the factors which might mostly regulate the presence of this species during the year are daylength and temperature. Indeed, the rise of the population begins in spring, when the daylength increases, and proceeds in summer, when also the seawater temperature grows. The increased number of daylight hours could optimise the photosynthetic yield of plastids retained by this sacoglossan, while the high summer temperatures might maximise its metabolism linked to the warm-water affinity.

In this study, as also reported in Perrone (1983), several white pigmented $B$. mimetica's specimens have been found. Ros (1976) stated that in reality $B$. mimetica has white pigments and the green coloration comes from the chloroplasts of $H$. tuna. Therefore, possibly the individuals tend to become white when they do not eat since a long time or because they do not eat enough. Indeed, probably,
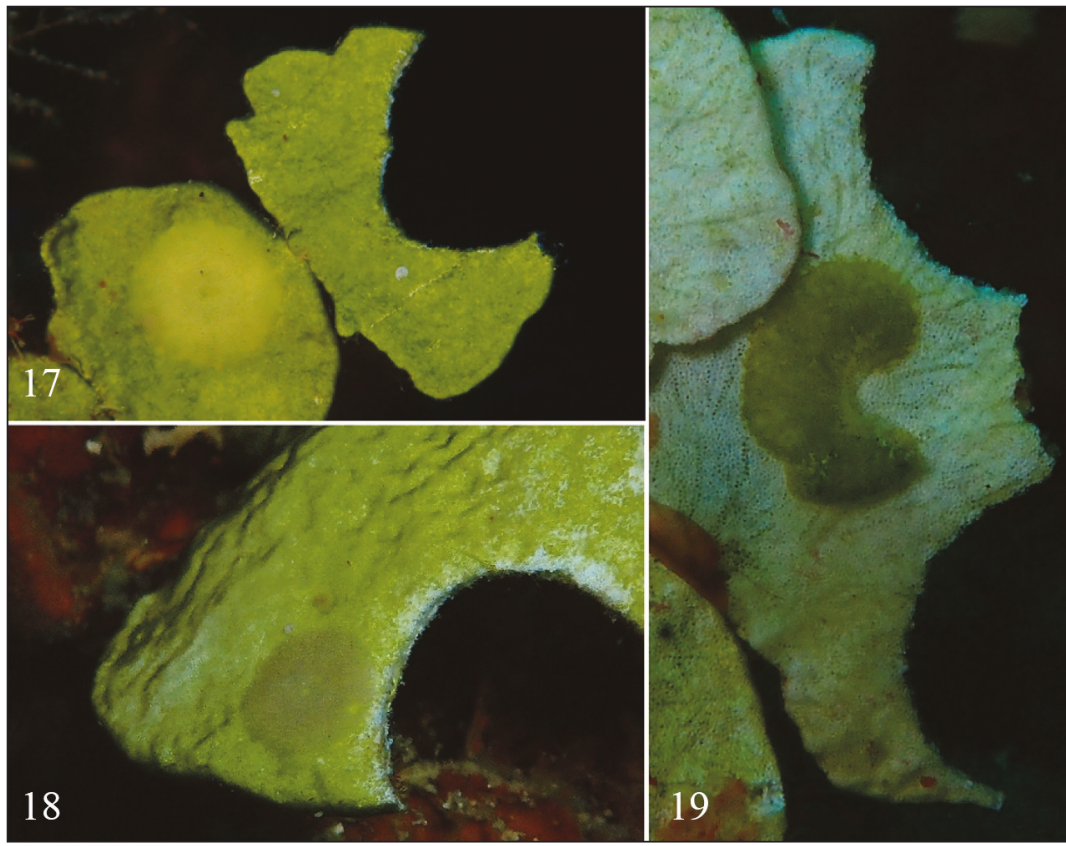

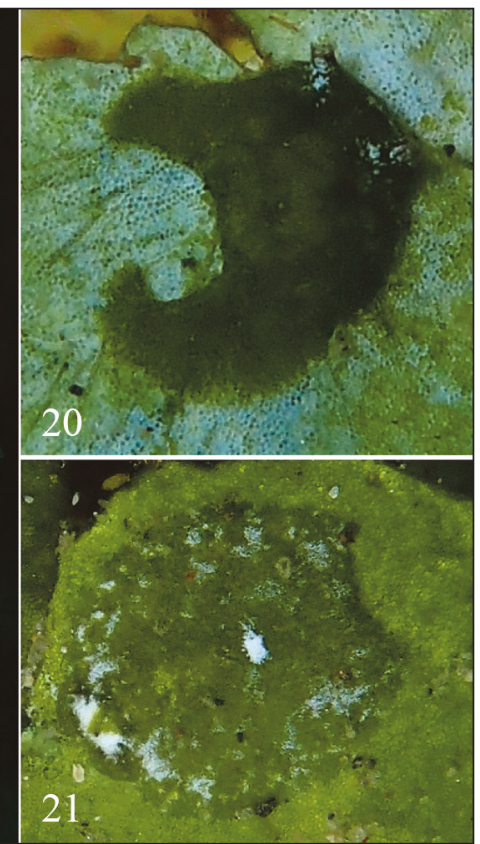

Figures 17-21. Some examples of crescent-shape bites. Fig. 17: a bite on a segment of H. tuna. Fig. 18: a bite close to $B$. mimetica's egg mass. Fig. 19: specimen injured on a thallus bitten several times; Fig. 20: another example of bitten $B$. mimetica; Fig. 21: a specimen with a bite on the posterior part of the body (photos by A. Lombardo). 
the totally white-pigmented specimens represent individuals which did not eat for a long time, while the specimens with intermediate white and green coloration could be individuals who did not eat sufficiently.

This sacoglossan, as anti-predatory strategy, besides the cryptism, hires chemical substances from the alga, which probably makes the animal indigestible (Paul \& Fenical, 1987; Marín \& Ros, 2004). Nevertheless, throughout this study, several specimens with evident crescent-shape injuries perfectly related to bites, have been recorded. As well as numerous thalli of $H$. tuna with the same injuries have been noted. Consequently, $B$. mimetica is subject to involuntary predation by hypothetical herbivores which feed on H. tuna. In the Mediterranean Sea, the most probable candidate as possible grazer of this seaweed is the parrotfish Sparisoma cretense (Linnaeus, 1758). Indeed, in some studies realized in coral reefs (Walters et al., 2002; Multer \& Clavijo, 2004; Castro-Sanguino et al., 2016) most of the crescent-shape bites present on Halimeda spp. were provoked by parrotfishes. In support of this, recently, along the central-eastern coast of Sicily, the high presence of $S$. cretense's populations and their grazing impact on deep macroalgal communities has been reported by Marletta \& Lombardo (2020). Consequently, S. cretense could involuntarily prey on $B$. mimetica when it rests on $H$. tuna.

In conclusion, this is the first study which document the seasonality of $B$. mimetica in the Mediterranean. Generally, this sacoglossan is strongly present in spring and summer, period after which it starts to decline until the end of autumn. Occasionally, a few rare specimens can be found in winter months. The factors which mostly seem to control B. mimetica's seasonality could be the daylength and the temperature.

As highlighted by Clark (1994), sacoglossans appear to be regulatory species, fine-tuning the ecology of primary producers and in some cases their abundance and occurrence. Consequently, continuous studies on native sacoglossans of an area are critical to understanding the dynamics occurring in a given marine ecosystem. Indeed, $B$. mimetica represents a perfect example of this, living in a very close relationship with $H$. tuna, an alga that characterises the deep Mediterranean communities (Ballesteros, 1991).

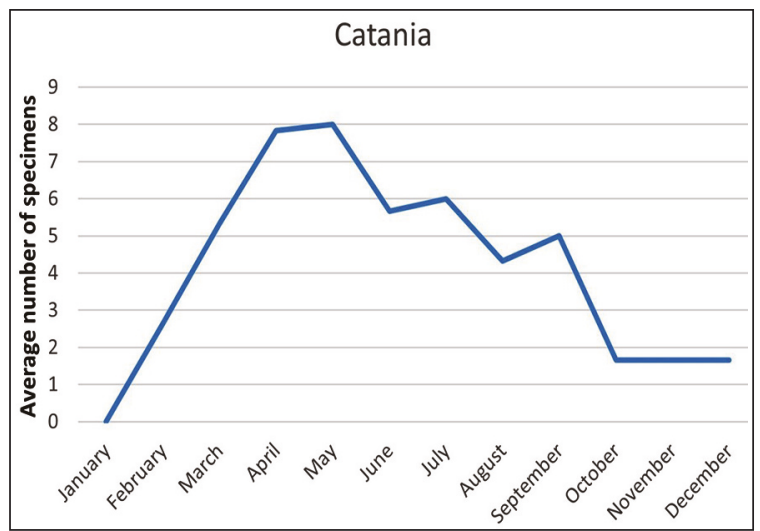

Figure 22. Seasonality of Bosellia mimetica in Catania, obtained by averaging the seasonal trends from 2018 to 2020.

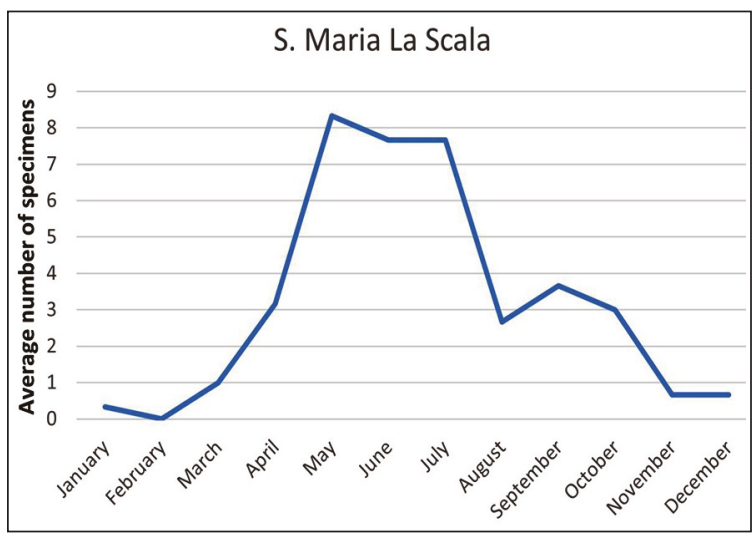

Figure 23. Seasonality of Bosellia mimetica in Santa Maria La Scala, obtained by averaging the seasonal trends from 2018 to 2020 .

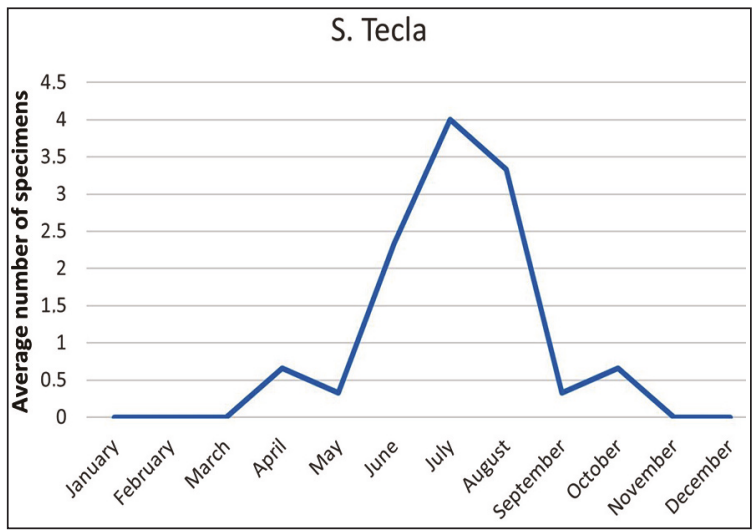

Figure 24. Seasonality of Bosellia mimetica in Santa Tecla, obtained by averaging the seasonal trends from 2018 to 2020. 


\section{REFERENCES}

Ballesteros E., 1991. Seasonality of growth and production of a deep-water population of Halimeda tuna (Chlorophyceae, Caulerpales) in the northwestern Mediterranean. Botanica Marina, 34: 291-301. https://doi.org/10.1515/botm.1991.34.4.291

Castro-Sanguino C., Lovelock C. \& Mumby P. J., 2016. The effect of structurally complex corals and herbivory on the dynamics of Halimeda. Coral Reefs, 35: 597-609. https://doi.org/10.1007/s00338-016-1412-5

Catra M., Giaccone T., Giardina S. \& Nicastro A., 2006. Il patrimonio naturale marino bentonico della Timpa di Acireale (Catania). Bollettino dell'Accademia Gioenia di Scienze Naturali, 39 (366): 129-158.

Clark K.B., 1994. Ascoglossan (=Sacoglossa) molluscs in the Florida Keys: rare marine invertebrates at special risk. Bulletin of Marin Science, 54: 900-916.

Händeler K., Grzymbowski Y.P., Krug P.J. \& Wägele, H. 2009. Functional chloroplasts in metazoan cells - a unique evolutionary strategy in animal life. Frontiers in Zoology, 6: 28. https://doi.org/10.1186/1742-9994-6-28

Marín A. \& Ros J., 1988. Los Sacoglosos (Mollusca, Opisthobranchia) del sudeste iberico. Catalogo de las especies y presencia de cloroplastos algales en las mismas. Iberus, 8: 25-49.

Marín A. \& Ros J., 2004. Chemical defenses in Sacoglossan Opisthobranchs: Taxonomic trends and evolutive implications. Scientia Marina, 68 (Suppl. 1): $227-241$. https://doi.org/10.3989/scimar.2004.68s1227

Marletta G. \& Lombardo A. 2020. Assessment of grazing impact on deep canopy-forming species in the western Ionian Sea, Central Mediterranean. International Journal of Aquatic Biology, 8: 365-376. https://doi.org/10.22034/ijab.v8i5.882

Meinesz A., 1980. Contribution à l'étude des Caulerpales (Chlorophytes). Ph. D. Thesis. Université de Nice.
Multer H.G. \& Clavijo I., 2004. Halimeda investigations: progress and problems. NOAA/RSMAS.

Paul V. J. \& Fenical W., 1987. Natural products chemistry and chemical defence in tropical alge of the phylum Chlorophyta. In: Scheuer P. J. 1987. Bioorganic Marine Chemistry. Springer, Berlin, 1-29. https://doi.org/10.1007/978-3-642-72726-9_1

Perrone A., 1983. Opistobranchi (Aplysiomorpha, Pleurobrancomorpha, Sacoglossa, Nudibranchia) del litorale salentino (mar Jonio) (Elenco - Contributo Primo). Thalassia salentina, 12/13: 118-144.

Portmann A., 1958. Über zwei wenig bekannte Ascoglossa des Mittelmeers (Gastr. Opisthobranchia). Revue Suisse de Zoologie, 65: 405-411.

Ros J., 1976. Sistemas de defensa en los Opistobranquios. Oecologia aquatica, 2: 41-77.

Ros J. \& Marín A., 1991. Adaptive advantages of the "symbiosis" between algal chloroplasts and sacoglossan molluscs. Oecologia aquatica, 10: 271298.

Schmekel R.L. \& Portmann A., 1982. Opisthobranchia des Mittelmeeres. Springer-Verlag., Munich, 410 pp.

Thompson T.E. \& Jaklin A., 1988. Eastern Mediterranean Opisthobranchia: Elysiidae (Sacoglossa = Ascoglossa). Journal of Molluscan Studies, 54: 59-69. https://doi.org/10.1093/mollus/54.1.59

Trainito E. \& Doneddu M., 2014. Nudibranchi del Mediterraneo. Il Castello, Cornaredo, 192 pp.

Trinchese S., 1890. Descrizione del nuovo genere Bosellia. Memorie della Reale Accademia delle Scienze dell'Istituto di Bologna, Classe di Scienze Fisiche, 5: 773-778.

Walters L.J., Smith C.M., Coyer J. A., Hunter C.L., Beach K.S. \& Vroom P. S., 2002. Asexual propagation in the coral reef macroalga Halimeda (Chlorophyta, Bryopsidales): production, dispersal and attachment of small fragments. Journal of Experimental Marine Biology and Ecology, 278: 47-65. http://dx.doi.org/10.1016/s0022-0981(02)00335-0 
